\title{
SOROS GERJESZTÉSÛ́ EGYENÁRAMÚ MOTOR SZIMULÁCIÓJA MATLAB KÖRNYEZETBEN
}

\section{SIMULATION OF A SERIES WOUND DC MOTOR IN MATLAB ENVIRONMENT}

\author{
Szántó Attila ${ }^{1}$, Szíki Gusztáv Áron ${ }^{2}$, Hajdu Sándor ${ }^{3}$, Gábora András ${ }^{4}$ \\ Debreceni Egyetem Müszaki Kar, Gépészmérnöki Tanszék, Cím: 4028 Debrecen, \\ Ótemetö u. 2-4., Telefon: +36 (52) 415-155 Fax: +36 (52) 418-643 \\ Iszanto930922@freemail.hu \\ 2 szikig@eng.unideb.hu \\ 3hajdusandor@eng.unideb.hu \\ 4andrasgabora@eng.unideb.hu
}

\begin{abstract}
The Department of Mechanical Engineering Faculty of Engineering University of Debrecen has a great experience in designing, developing and constructing race cars with alternative drive. For successful racing we have recently developed a vehicle dynamics simulation program [1] in MATLAB [2] environment which is capable of calculating the dynamics functions of a car from its technical data. Since most of our race cars have a series wound DC motor we have modelled and simulated this type of electric motors and built the simulation into our program. In this paper we present the way of modelling and simulation this type of motors.
\end{abstract}

Keywords: series DC motor, dynamics modeling, simulation, MATLAB

\section{Összefoglalás}

A Debreceni Egyetem Műszaki Karának Gépészmérnöki Tanszéke jelentős tapasztalattal rendelkezik alternatív hajtású járművek tervezésében, fejlesztésében és kivitelezésében. A versenyeken való minél eredményesebb részvétel érdekében MATLAB [2] környezetben kifejlesztettünk egy jármüdinamikai szimulációs programot [1], amely az irodalomból ismert és kísérletileg meghatározott müszaki adatokból, mint bemenő paraméterekből kiszámítja a versenyautó menetdinamikai függvényeit. Versenyautóink többsége soros gerjesztésű egyenáramú motorral hajtott, így alapvető fontosságú a fenti motor modellezése, és a modell alapján készített szimulációs programblokk beépítése a jármüdinamikai szimulációs programunkba. A következőkben a fenti motor modellezését és szimulációját mutatjuk be.

Kulcsszavak: soros gerjesztésü egyenáramú motor, dinamikai modellezés, szimuláció, MATLAB

\section{A motor dinamikai modellje}

A továbbiakban a soros gerjesztésü egyenáramú motort [3] modellezzük. A motor modelljének blokkvázlata az 1. ábrán látható. $\mathrm{Az}$ ábra alapján a motort jellemző elektromágneses és dinamikai egyenletek az alábbiak [4], [5]: 


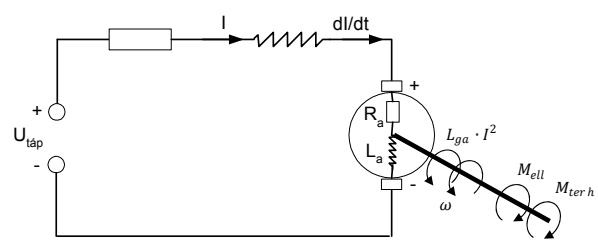

1. ábra. A soros gerjesztésü egyenáramú motor modellje (Forrás: [4])

Elektromágneses egyenlet:

$$
\begin{aligned}
& U_{\text {táp }}-\left(R_{a}+R_{g}\right) \cdot I-\left(L_{a}(I)+L_{g}(I)\right) . \\
& \frac{d I}{d t}-L_{g a}(I) \cdot \omega \cdot I=0
\end{aligned}
$$

Dinamikai egyenlet:

$$
\underset{\frac{d \omega}{d t}}{L_{g a}(I) \cdot I^{2}-M_{t e r h}(\omega)-M_{e l l}(\omega)=J_{m}} .
$$

A fenti egyenletekben $U_{\text {táp }} \quad$ az akkumulátor kapocsfeszültsége, $R_{a}$ és $R_{g}$ pedig az armatúra és gerjesztő tekercs ohmos ellenállása. Az $L_{a}(I)=\frac{\partial \Psi_{a}(I)}{\partial I}$, $L_{g}(I)=\frac{\partial \Psi_{g}(I)}{\partial I} \quad$ és $\quad L_{g a}(I)=\frac{\partial \Psi_{g a}(I)}{\partial I}$ mennyiségek az armatúra és gerjesztő tekercs dinamikus öninduktivitása, valamint a két tekercs kölcsönös dinamikus induktivitása, $\Psi_{a}(I), \Psi_{g}(I)$ és $\Psi_{g a}(I)$ pedig a hozzájuk tartozó mágneses fluxusok. Mint korábban említettük, a fenti mennyiségek mindegyike függ a motoron átfolyó áram erösségétöl. Az $M_{\text {terh }}(\omega)$ és $M_{\text {ell }}(\omega)$ mennyiségek a motort terhelö nyomatékok, amelyek függnek a motor fordulatszámától. Az előbbi a jármü mozgatásából az utóbbi a motor csapágyellenállásából adódik. A $J_{m}$ mennyiség a motor forgórészének tehetetlenségi nyomatéka. Az $L_{a}(I), L_{g}(I)$, $L_{g a}(I)$ és $M_{e l l}(\omega)$ karakterisztikákat mérés útján kell meghatározni. $J_{m}$ értéke szerepelhet a motor katalógusában, vagy ki kell mérni. Az $M_{\text {terh }}(\omega)$ karakterisztikát a program számítja a jármú jellemzőiből.

\subsection{A MATLAB környezetben írt motor szimulációs program}

A motor szimulációs programblokkot az (1) és (2) egyenletek alapján MATLAB környezetben fejlesztettük ki, illeszkedve ez által a korábbi jármüdinamikai szimulációs programunkhoz. A motor szimulációs program blokkdiagramját az alábbi ábra mutatja:

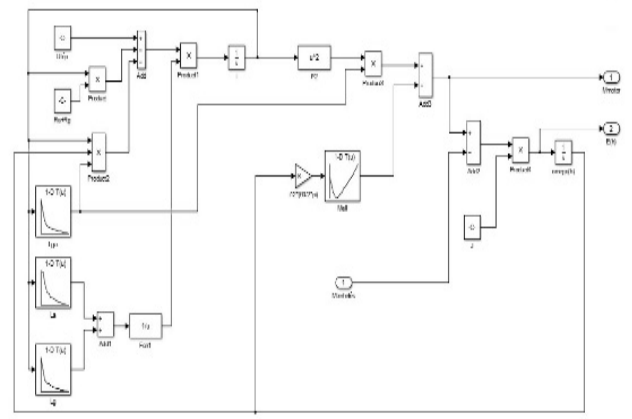

2. ábra. $A$ motormodell alapján MATLAB környezetben készült szimulációs program

A mérés útján meghatározott $L_{a}(I)$, $L_{g}(I), L_{g a}(I)$ és $M_{\text {ell }}(\omega)$ karakterisztikákat „lookup table"-k formájában építettük be a programba, míg az $U_{\text {táp }}, R_{a}, R_{g}$ és $J_{m}$ mennyiségek konstansok formájában szerepelnek. A „lookup table”-ben tárolt mennyiség értékét az aktuális áramerősség illetve szögsebesség függvényében olvassa be a program.

\section{A bemenő modellparaméterek kísérleti meghatározása}

A szimulációs program futtatásához a bemenő müszaki paraméterek értékét ismernünk kell.

A fenti paraméterek kísérleti meghatározását a Debreceni Képző Központtal (DKK) együttmüködésben végeztük. Az említett paraméterek az alábbiak: a motorban lévő tekercsek ohmos ellenállásai, továbbá dinamikus ön- és kölcsönös induktivitásuk, valamint a 
forgórész csapágy ellenállási és tehetetlenségi nyomatéka.

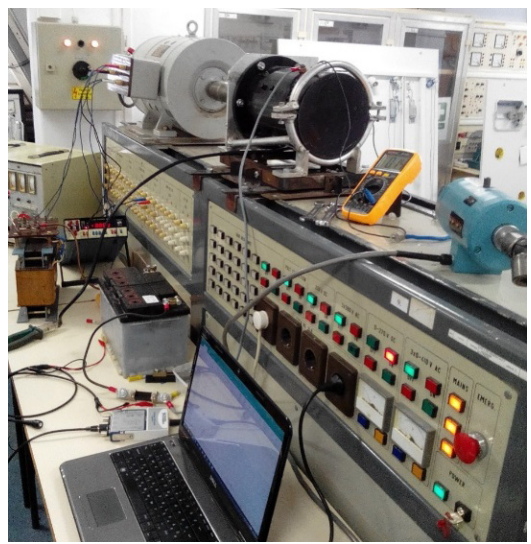

3. ábra. Kísérleti elrendezés a DKK-ban

A mérések részletes leírás a [6] irodalomban található.

\section{Szimulációs eredmények}

A motor szimulációját különböző terhelö tehetetlenségi nyomatékok mellett végeztük el. Nevezetesen a motor forgórészének tehetetlenségi nyomatékát $25,50,75,100$ és $10000 \mathrm{~kg}$ tömegü, $20 \mathrm{~cm}$ átméröjü, homogén tömegeloszlású korongnak megfelelő tehetetlenségi nyomatékokkal növeltük meg. A programot lefuttatva rögzítettük a motor által kifejtett nyomatékot, a rajta átfolyó áram erősségét és a motor fordulatszámát az idő függvényében. Az alábbi ábrák ezeket a függvényeket szemléltetik.

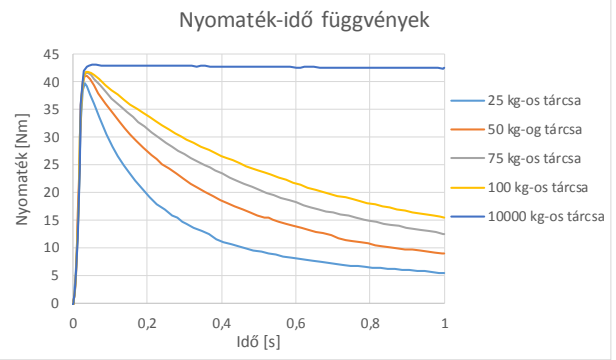

4. ábra. A motor által kifejtett nyomaték az idő függvényében

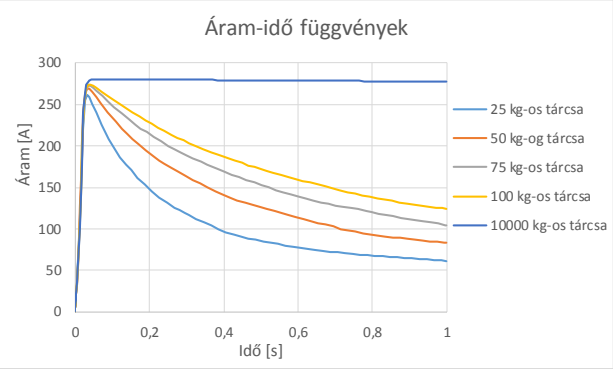

5. ábra. A motoron átfolyó áram az idő függvényében

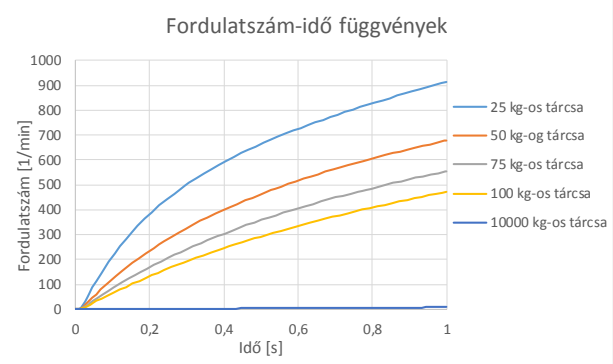

6. ábra. A motor fordulatszáma az idö függvényében

Az 10000 kg-os tömeg gyakorlatilag a rögzített forgórészű motort modellezi. Látható, hogy ebben az esetben a szögsebesség az adott 1 [s] időtartamban közelítőleg zérus. Azaz a rögzített forgórészü motor szimulációját megvalósíthatjuk a szögsebesség zérus értékben történő rögzítésével, vagy a forgórész tehetetlenségi nyomatékának „végtelen nagy” értékü megválasztásával.

Látható az is, hogy az áramerősség és a nyomaték csúcsértéke közelítőleg ugyanazon időpillanathoz tartozik, erre magyarázatot az $M_{\text {motor }}=L_{g a}(I) \cdot I^{2}$ összefüggés szolgáltat.

\section{Tesztmérések és következtetések}

A mért ohmos ellenállások és dinamikus induktivitások pontosságát, valamint a szimulációs programunk megfelelő működését tesztmérésekkel ellenőriztük. A 
tesztmérések során a rögzített forgórészü motorra rákapcsoltuk a feszültséget és mértük az áramerősség és forgatónyomaték időbeli felfutását. Az alábbi ábra az áramerösséget mutatja az idő függvényében.

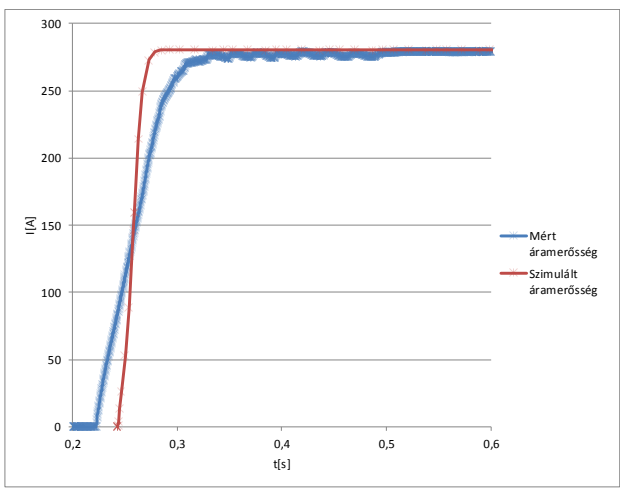

7. ábra. Az áramerösség időbeli felfutásának vizsgálata. A mérés során a motor forgórészét rögzitettük, majd a motorra pillanatszerüen rákapcsoltuk a feszültséget. (Forrás: [6])

A szimuláció és tesztmérések eredményeinek jó egyezéséből arra következtetünk, hogy az új dinamikus motormodell, és a rá épülő szimulációs program az elvárásoknak megfelelően múködik.

A motor szimulációjával kiegészített jármüdinamikai programban már a motor feszültsége is szabályozható, így különbözö teljesítmények esetén el tudjuk végezni a szimulációt. Mivel így már a motoron eső feszültség és rajta átfolyó áramerősség időfüggése is szimulálható, meghatározható a motor pillanatnyi teljesítménye az idő függvényében.

\section{Szakirodalmi hivatkozások}

[1]Szántó Attila: Elektromos hajtású tanszéki versenyautó jármüdinamikai modellezése, TDK dolgozat (2015), Debreceni Egyetem Müszaki Kar.

[2] MATLAB 2014b, The MathWorks, Inc, Natick, Massachusetts, United States.

[3]http://webaruhaz.permanent.hu/termek/elektr omos auto-1-motorok135/dc48v_os_4kw_os_soros_villanymotor187

[4] Szántó Attila, Szíki Gusztáv Áron, Hajdu Sándor: Soros gerjesztésü egyenáramú motorral hajtott versenyautó dinamikai modellezése, Müszaki Tudomány az ÉszakKelet Magyarországi régióban 2016, szerk. Bodzás Sándor, Debreceni Akadémiai Bizottság Műszaki Szakbizottsága, Debrecen, 406-414, 2016.

[5] Miralem Hadžiselimović, Matic Blaznik, Bojan Štumberger, Ivan Zagradišnik: Magnetically Nonlinear Dynamic Model of a Series Wound DC Motor, Przegląd Elektrotechniczny (Electrical Review), ISSN 0033-2097, R. 87 NR 12b/2011

[6] Gál Tibor: Soros gerjesztésü egyenáramú motor elektromágneses és dinamikai jellemzőinek mérése, TDK dolgozat (2016), Debreceni Egyetem Müszaki Kar 